\title{
Potential Effect of Micrornas as Biomarkers and Therapeutic Targets in COVID-19
}

\author{
Walaa Fikry Elbossaty* \\ Department of Biochemistry, Damietta University, Egypt.
}

Submission: January 20, 2021; Published: January 25, 2021

*Corresponding author: Mohammad Taghi Sheykhi, Professor Emeritus of Sociology, Alzahra University, Iran

\begin{abstract}
One of the main reasons that cause the Corona pandemic is the occurrence of a disorder or defect in the immune response against microbes, including Covid 19 virus. Despite the material and human losses caused by the Covid 19 virus, there is still no effective treatment or rapid diagnostic tool for Covid 19 infection. Therefore, studies recently sought to search for an easy way to diagnose and may at the same time be a reason for treatment of the virus. Scientists have tried to link the immune system with many genes, especially this group known as microRNAs, the extent of infection with the Covid 19 virus and the way the body's immune response to it.
\end{abstract}

Keywords: Covid19; microRNA; Corona pandemic

\section{Mini Review}

After the terrible spread of the Covid 19 virus, studies have sought to discover the genetic makeup of the virus, hoping to discover the genetic mutation responsible for that. It has been found that there is a unique sequence of amino acids that differs from the rest of the viruses that infect the respiratory system such as MERS and SARS, which facilitate the process of virus entry into the cell. It has been found that the receptor for the virus inside the cell is angiotensin-converting enzyme 2 (ACE2) [1].

This may be explained by the fact that patients with high blood pressure are characterized by an abnormality of angiotensinconverting enzyme 2 (ACE2). More susceptible and deteriorating to contracting the virus [2]. MicroRNAs are non-coding RNAs that bound at the $3^{\prime}$-untranslated region (3'-UTR), and this group plays an important role in regulating gene expression [3]. MicroRNAs consist of 18-25 noncoding nucleotides. The microRNA has a dual role, as it may be a vital tool to ensure virus infection in addition to being an effective treatment [4].

In the event that it is used as a treatment, microRNAs are inserted into the cell via phagocytosis, endocytosis, or direct fusion and act as a bio stimulator or endocrine regulators (Figure 1) [5]. It was found that there is a negative relationship between the microRNA and the ribonucleic acid of the Covid 19 virus, as it causes the virus to stop translating the genetic code to the virus and thus affects its activity, reducing or dampening the virus's life cycle, thus losing its ferocity and thus it is easy to overcome [6]. When infected with Covid-19 virus, the immune system is stimulated and the natural immunity increases, so immune cells secrete TNF, IL-1 $\beta$, IL-6, IL-8, G-CSF and GM-CSF, as well as chemokines, such as MCP1, IP10 and MIP1 $\alpha$, which in turn, it increases the risk of developing respiratory diseases and heart failure [7]. Therefore, if the existing genetic sequence of the virus is controlled, this process will stop and the virus is eliminated and this is done through microRNA injection [8].

\section{Conclusion}

The mechanism of action of microRNA depends on the ability to enter the cell through multiple methods, and then it binds to the mRNA of the Covid 19 virus, and it is a compound that has the ability to inhibit the protein synthesis process responsible for the virus's activity and its severe symptoms, and then this leads to inactivation and elimination of the virus at a faster rate time. Though microRNA have therapeutic and diagnostic tool in Covid 19 infection. 


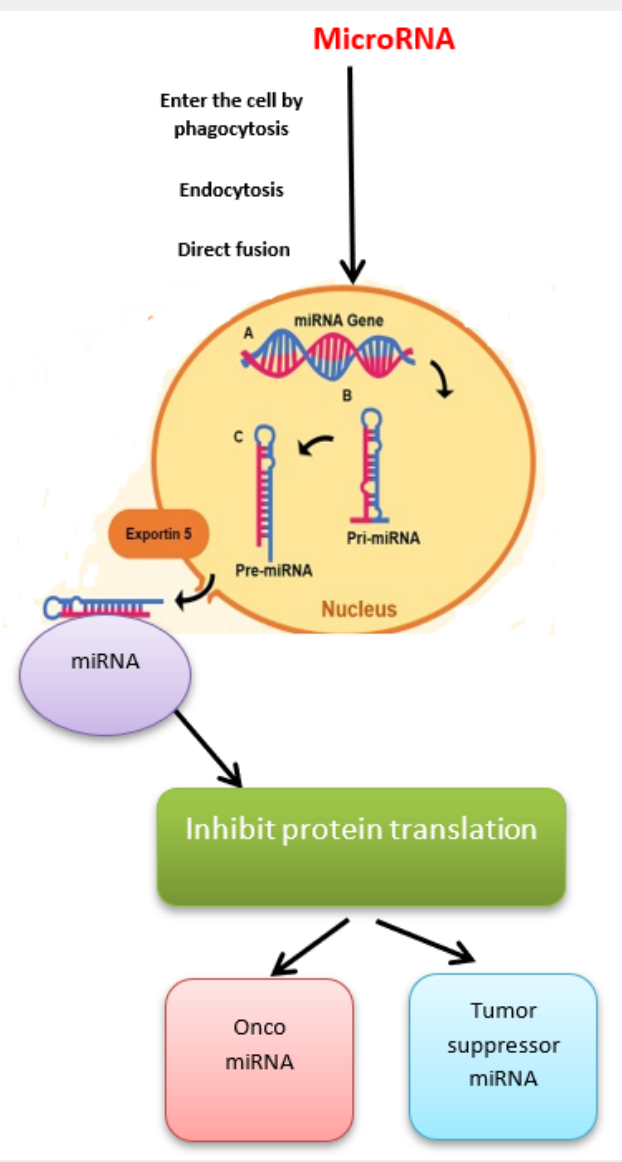

Figure 1: miRNA biogenesis inside the cell.

\section{References}

1. Domenico B, Silvia A, Marta G, Martina B (2020) Evolutionary analysis of SARS-CoV-2: how mutation of Non-Structural Protein 6 (NSP6) could affect viral autophagy. J Infect 81(1): e24-e27.

2. Mahmoud G, Kaiming W, Anissa V, Quynh N (2020) AngiotensinConverting Enzyme 2: SARS-CoV-2 Receptor and Regulator of the Renin-Angiotensin System. Circ Res 126(10): 1456- 1474.

3. Hui L, Muller F, George A (2013) MicroRNAs and other non-coding RNAs as targets for anticancer drug development. Nat Rev Drug Discov 12(11): 847-865.

4. Leigh-Ann M, Paul R (2010) MicroRNA: Biogenesis, Function and Role in Cancer. Curr Genomics 11(7): 537-561.
5. Ancuta J, Oana Z, Cornelia B, Vladimir L (2020) A comprehensive picture of extracellular vesicles and their contents. molecular transfer to cancer cells. Cancers (Basel) 12(2): 298.

6. Sobhy H, Mohamed E, Mostafa E (2020) A new approach for COVID-19 treatment by micro-RNA. Med Hypotheses 143: 110203.

7. Víctor J, Rebeca M, Jose M, Concepción R, Melguizo-Rodríguez L, et al. (2020) SARS-CoV-2 infection: The role of cytokines in COVID-19 disease. Cytokine Growth Factor Rev 54: 62-75.

8. Ruth E, Daniel O, Andrew J (2017) The clinical application of microRNAs in infectious disease. Front Immunol 8: 1182. 
CC This work is licensed under Creative
Your next submission with Juniper Publishers will reach you the below assets

- Quality Editorial service

- Swift Peer Review

- Reprints availability

- E-prints Service

- Manuscript Podcast for convenient understanding

- Global attainment for your research

- Manuscript accessibility in different formats ( Pdf, E-pub, Full Tsext, Audio)

- Unceasing customer service

Track the below URL for one-step submission https://juniperpublishers.com/online-submission.php 